\title{
Paperless Office Management: A Feasibility Analysis for Saudi Arabia Government Offices: Case Study in Ministry of Labor
}

\author{
Saleh Rehiel A Alenazi \\ School of Computing, College of Arts and Sciences (CAS) \\ University Utara Malaysia, Malaysia \\ E-mail: sala207@hotmail.com \\ Abdul Jaleel Kehinde Shittu \\ School of Computing, College of Arts and Sciences (CAS) \\ University Utara Malaysia, Malaysia \\ E-mail: abdjaleel@uum.edu.my
}

Ebrahim Mohammed Al-Matari

Faculty of Business and Economics, Ammran University

Yemen and Othman Yeop Abdullah Graduate School of Business

University Utara Malaysia, Malaysia

E-mail: ibrahim_matri@yahoo.com

Ayed Rheal A. Alanzi

College of Science and Human Studies at Hotat Sudair

Mathematics Department, Majmaah University, Kingdom of Saudi Arabia

E-mail: auid1403@hotmail.com

Received: May 29, 2014

doi:10.5296/jmr.v6i3.5700
Accepted: July 10, 2014

Published: July 10, 2014

URL: http://dx.doi.org/10.5296/jmr.v6i3.5700 


\section{Abstract}

This paper aims to propose paperless office management policies for Saudi public offices. It proposes policy and implementation strategy for Ministry of Labor, as this ministry directly deals with citizens and foreign workforce. Recent statistics shows that in 2010, the Middle East alone consumed 18 million tons of paper in private and public sectors for various business correspondence and education activities. This extensive consumption of paper is causing two major problems for Saudi Arabia, Middle East as well as the world at large. Firstly, widespread use of paper results in decrease in productivity and efficiency. Secondly, paper manufacturing industry is a major contributor to environment degradation, green house gas emission and pollutions. The report proposes five course action plans to develop a paperless office. This policy is proposed in accordance with Basic methods of Policy Analysis and Planning of Patton and Sawicki. Because this policy can face legislative and cultural barriers, a thorough implementation plan is required to ensure maximum success. Saudi government can benefit from this policy in various ways such as, increased success rate of 'Nitaqat' program.

Keywords: Paperless Office Management, Saudi Arabia Government, Ministry of Labor 


\section{Introduction}

Recent statistics show that in 2010, Middle East alone consumed 18 million tons of paper in private and public sectors for various business correspondence and education activities. It is estimated that by 2020, the region will consume 29 tons of paper for the same purposes. Indonesian Pulp and Paper Association reported that tons of paper is consumed due to extensive application of technology. In 2010, global paper consumption was reduced by 1.1 million. Nevertheless, the appeal of technology did not considerably affect the Middle East but with rapid business growth in the region, the demand for paper increased from previous years. The association also reported that the demand for paper is relatively higher in Saudi Arabia and Egypt as compared to other countries in the region (AME, 2011). A recent study revealed that Saudi Arabia's annual paper consumptions in 2005 was 3.5 million tons, which indicates the per capita paper consumption in the same country was $38.6 \mathrm{~kg}$ per annum (Jeffreys, 2009). This extensive consumption of paper is causing two major problems for Saudi Arabia, Middle East as well as the world. Firstly, widespread use of paper results in decrease in productivity and efficiency and record keeping constitutes more than $90 \%$ of all office activity. Secondly, paper manufacturing industry is a major contributor to environment degradation, greenhouse gas emission and pollutions. Additionally, manufactured paper is accounted for around 35 percent of municipal solid waste by weight (US EPA, 2012). This paper aims to propose paperless office management policies for Saudi public offices. Due to time and resource constraint, this study will propose possible policy and implementation strategy for Ministry of Labor, as this ministry directly deals with citizens and foreign work force. The procedures generally involve filling of various forms which is time consuming and often causes delays in completion of applications.

The paper making industry was once dependant on virgin forests and old trees for pulps. These trees take more than one hundred years to grow and are virtually non-renewable. But constant pressure of environmental activists leads pulp industry to search for renewable forestry plantations for pulp source. However, many Asian pulp producers are not aware of the adverse effects of deforestation and as a result deforestation continues and environmental concern is grossly overlooked in this region (National Geographic, 2013). It is necessary to mention that Indonesia and China is two of the major paper suppliers of Saudi Arabia (AME, 2011), where environmental concern is grossly overlooked.

As of 2004, worldwide paper consumption has increased $400 \%$ in the last 40 years (Martin, 2004). Moreover, 35\% of harvested trees go for pulp manufacturing (Martin, 2004). Logging and cutting of old trees has minimized over the years mainly due to lack of availability and environmental concerns and old trees only contribute around $10 \%$ to the current paper industry (Martin, 2004). Manufacturers are using monoculture agro-technique for wood harvest but it is said that monoculture creates imbalance in the ecology (Greenblue, 2013).

The pulp industry also faces criticism for heavy use of chemicals like chlorine compounds and chlorine. Paper mills are known for using toxic chemicals to make pulp from wood. The by-products of this industry are mercury, water effluents, solid waste (e.g. boiler ash) and total suspended solids (e.g. effluent sludge). These chemicals are hazardous to environment 
(National Geographic, 2013). Apart from negative environmental effect, extensive paper usage reduces productivity and efficiency of a business (Harrison, 2013). Saudi Arabia's public offices have traditional paper based filing system. It involves usage of filing cabinets, shelves, folders and microfiche systems. All of these require procurement, big office spaces and constant maintenance. Overall, the practice is resource intensive. The offices uses printer to print important papers and file it. This practice makes the data out of synchronization, as a result it becomes difficult to arrange and search when necessary. Nevertheless, it is often experienced that despite storing several copies of one file, the files cannot be found when necessary. So the whole process needs to be started from the beginning. Moreover, tracking a file in paper based system is not only time consuming but it is also difficult and expensive.

In order to minimize environmental footprint and increase efficiency, the paper proposes Saudi Arabia's Ministry of Labor to adopt paperless office management. The major stakeholders of this ministry is government, public and foreign employees. This proposed policy can benefit stakeholders from different directions. The government and the ministry can save money and other resources. Moreover, these initiatives circulate positive public relation messages worldwide, and the government can enjoy superior reputations. To be more precise, this initiative will allow Saudi Government to actively take part in environmental conservation activities. Public and foreigners can benefit from this as job related processes and procedures would be simplified and relatively faster.

\section{Background of E-government}

A simpler E-government definition is, it automates the delivery of government services (Seifert, 2013). This paper is going to discuss automation process of Ministry of Labor of Saudi Arabia. As it was mentioned earlier paper management and record keeping occupies $90 \%$ of office time and resources so it is proposed that the ministry adopt paperless office system. Currently Ministry of Labor deals with all kind of job related issues, placements and legislations in Saudi Arabia. Though along with other ministries, Ministry of Labor partially uses IT technology to serve people, however, job application, job extension, new work permit, work permit extension etc. are heavy paper intense. An applicant needs to fill up several paper forms to apply for a job. Moreover, companies who hire expatriates need to go through several processes to hire a foreigner or extend job duration in the country. Recent news shows that Ministry of Labor wants to create 600,000 new jobs for Saudi nationals (Reuters, 2013). The ministry reported that it is turning into a difficult task to convince this much citizens to work despite of the fact that Saudi local population unemployment rate is $12.2 \%$ (Reuters, 2013). Another survey reported that 29,000 households do not have any working person in the family. Complex application process and misplace of application could be one of the reasons for Saudi nationals to try second time. Moreover, private companies who are one of the big contributors of Saudi economy also showing concerns about complex expatriate recruit and retain systems (Reuters, 2012). As Saudi government is aggressively trying to occupy majority of its labor force by local people the government should consider making the application process easier so that local gets encouraged in applying and working. 


\section{Macrothink}

Journal of Management Research

ISSN 1941-899X

2014, Vol. 6, No. 3

Recently the ministry has introduced labor portal for its existing labors. Study shows that the results are satisfactory for beginner, $78 \%$ respondents believed that the portal is usable and serves purpose, however, 22\% respondents perceived that it needs improvements (AL-Zuabi \& Al- Shaikhli, 2013). This study clearly shows that Saudi government has the potential to implement E-government systems that means it's viable to attempt paperless office management.

\section{E-Government Concept}

One school of thought referred e-government facilities specific actions such as receiving job information, applying for passport and other social security benefits using IT. Other observers simplified the definition by saying e-government automates the delivery of government services. The Gartner Group came up with a comprehensive definition saying that e-government can be regarded as "the process through which service delivery, constituency, governance and participation can be maximized continuously through internet, media and other technology with the purpose of smoothen the relationships that exist between government and other stakeholders(Seifert, 2013).

In classifying e-government activities, different schools of thought have come up with different concepts. In the position of Seifert, (2013), these activities can categorized into 3 such as government-2-business (G2B), government-2-citizen (G2C) and government-2-government (G2G). In another realm, Hwang et al., (2004), conceptualized such activities into 8 groups which include government-2-citizens (G2C), citizen-2-government (C2G), government-2- officeholder (G2O), business-2-business (B2B), business-2-government (B2G), government-2- government (G2G), government-2- business (G2B) and citizen-2- citizen (C2C). However, this study shall focus on three major areas of e-government activities which include government-2-business (G2B), government-2-citizen (G2C), and government-2-government (G2G). 


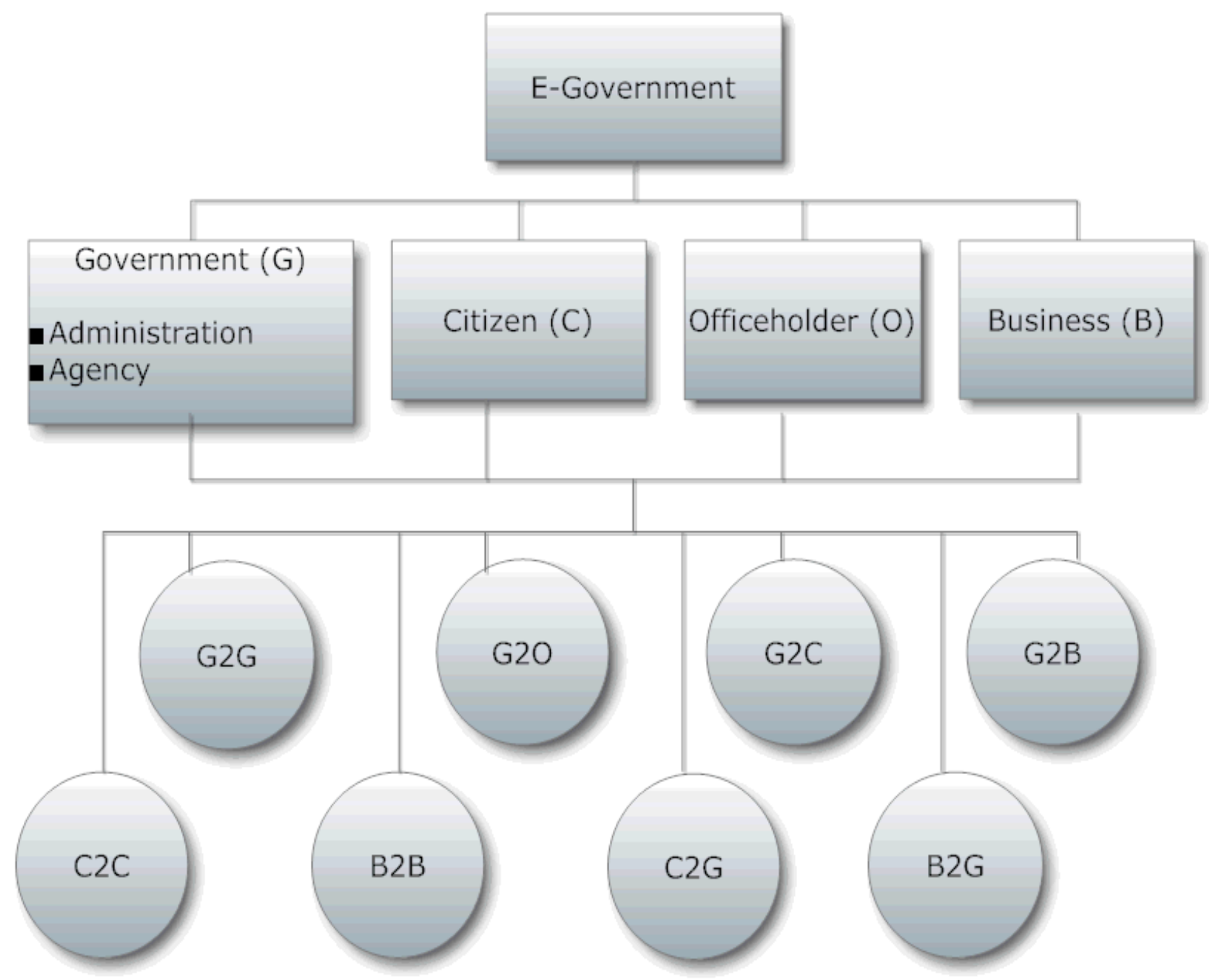

Figure 1. Complex nature of e-government: (Data Source: (Hwang et al., 2004)

\section{E- Government in Saudi Ministry of Labor}

The Ministry of Labor is required to cater the need of government-to-government (G2G), government-to-business (G2B), and government-to-citizen (G2C) communication. Different ministries and departments require getting information from ministry of labor for various administrative purposes e.g. legislations. Likewise, businesses especially private sector needs to contact labor ministry for employment availability, recruitment, extensions etc. businesses also receives legislation updates from this ministry (Ministry of Labour Saudi Arabia, 2013). Similarly, citizen as well as foreign nationals needs to correspondence with this ministry for potential or existing job related issues. So it can be said that this ministry is extremely important to ensure smooth functioning of labor market which is a very important component of public administration. As it is mentioned earlier that the ministry already using e-government policies up to some extend to cater the need of different stakeholders e.g. labor portal (AL-Zuabi \& Al- Shaikhli, 2013). However, the functionality of this portal is limited. 
Moreover, the usability and acceptability of this portal is also a subject to further testing. This study aims to discuss two key concerns of Saudi Ministry of Labor, firstly, how to attract Saudi local people to join labor force. Secondly, how to provide hassle free services to businesses especially private firms.

Recent census data shows that Saudi has a population of 29.1 million, where 10 million are expatriates and 19 million is Saudi own population. Contrary to government $5.5 \%$ rate of unemployment, Reuters (2013) reported that Saudi Arabia's unemployment rate is $12.2 \%$ Various credible sources reported that Saudi national are unwilling to work. Many eligible workers do not attempt second time to get a job (Reuters, 2013). There are many reasons behind this reluctance, one of the reasons is complicated paper based application process of ministry of labor. Several incidences was reported that application went missing and the applicant requires to start all over again. Moreover, a typical application process requires filling same form more than two times and submitting hardcopies. This complex process can be a major de-motivating factor for eligible work force.

Another concern of ministry of labor is communication with business entities. Saudi Arabia has 800,000 listed companies. Under Nitaqat programme ministry of labor categorized companies into three zones namely green, yellow and red. Green companies are privileged, there expatriate visa and other formalities processing requires least amount of time whereas other two zones has to go through paper intense processes and sometimes wait longer time to complete procedures (Murphy, 2011). These private companies contribute to 40\% of Saudi's GDP (Michigan State University, 2011). These undesirable sufferings to private sectors mostly due to paper intense procedures may result in decrease in entrepreneur's motivation. ILO report shows that though Saudi government wants to eradicate employment imbalance but due to many practical problems this is a difficult task (ILO, 2011). It is suggestive to ministry of labor that it should ease the process of application for recruitment and extension as the country cannot survive without active support from foreign labor force. This process simplification can be started by making a paperless office management. In order to do so it is necessary to understand challenges of e-government.

E-government system can benefit citizens, businesses, and governments in numerous ways around the world. Though it has been said that such activities are still very new, however with the transformative power of internet which can make communication to be effective at high speed and lower cost, important milestones can be achieved (Jaeger \& Thompson, 2003). But it has significant challenges. Researchers have identified 4 distinct barrier of e-government implementation namely technical, political, cultural, legal (Hwang et al., 2004).

Technical Barriers: basically it discusses whether the country has adequate IT structures, how government is planning to promote new technology, is there any secure mechanism. In Saudi context it can be said that government clearly has adequate IT infra-structure. Recently Saudi Arabia converted labor environment from respective office and ministry to central environment which is said to world largest e-government initiatives. The ministry has adopted MS system which is a new technology and it helps to avoid incidence of duplication 
and inaccuracies. The government also established Project Management Office PMO to supervise IT implementation matters (AL-Zuabi \& Al- Shaikhli, 2013).

\subsection{Political Barriers}

Iin order to reduce expatriates and private companies suffering and increase participation of local labor force political barriers are main negative force. As it was mentioned earlier that recent legislation changes made it difficult for expatriates as well as hiring companies difficult to operate in Saudi Arabia (Shane, 2012). Similarly as government is operating incentive centric policies (Reuters, 2013) it is also becoming difficult to get willing local workers.

\subsection{Cultural barriers}

World Bank report shows that around $17.7 \%$ Saudi population lives in rural areas. Among them 33\% are unemployed (World Bank, 2013) and actively seeking employment opportunities. Most of these rural dwellers are computer illiterate therefore the acceptability of e-government is relatively lower among these people. Moreover, it is seen that there is lack of trust among rural and many urban people towards IT services, many still prefers traditional paper based system.

\subsection{Legal barriers}

Generally legal system of e-government deals with organized network crime and IT protection laws. Data shows that overall crime rate of Saudi Arabia is low and incidents of network crime are unknown. however, the increasing online attacks refers that Saudi can be affected too. There is no official IT law in Saudi however it is generally discussed in chapter 5 and chapter 7 in the Basic Law of Governance (Saudi Goverment, 2013).

As a result of various political, technical and economic reasons, it may take some period before the potential and impact of e-government to be fully felt. Various scholars have divided the projects of e-government into 4 stages of evolution and this includes presence, presence, interaction, transaction, and transformation (Seifert, 2013).

Moreover, in order to implement a new project ministry of labor needs to build suitable front office and back office in order to ensure maximum success. UN outlines front office as "to the government as its constituents see it, meaning the information and service providers, and the interaction between government and both citizens and businesses.” (Janowski, 2003) And UN referred Back office as "the internal operations of an organization that support core processes and are not accessible or visible to the general public.” (Janowski, 2003).

\section{Alternative Policy}

In previous chapter existing employment processing complexities were discussed. Now the report intends to propose a new policy for Saudi Ministry of Labor. Introduction of portal based employment system and minimize paper usage by making paperless office.

Ministry of Labor can learn from Malaysian government initiatives. In 1990s Malaysia government has started e-government initiatives by implementing seven flagship programs. 
One of the important pilot projects of Multimedia Super Corridor was Electronic Labor Exchange (ELX). This is a dedicated portal for Malaysian citizen to learn about labor market and apply for employment in public and private sectors (Noor et al., 2011).

ELX have three modules namely Job Clearing System (JCS), Labour Market Database (LMD), Office Productivity Support System (OPSS). Under JCS an applicant can use online automatic job matching system. LMD consolidates and represent labor market database. OPSS provides strategies to enhance productivity and efficiency (UNPAN, 2008). Malaysian Human Resource Minister said that about 25\%\% of all job vacancies in Malaysia are filled though the Electronic Labour Exchange (ELX) system (The Star Online, 2006). Saudi can reciprocate similar model for its potential and existing job market instead of using current paper based application system.

A paperless office is a working environment where the use of paper is minimal. Generally this can be done by converting data, files and document into digital format. Experts claim that paperless office management can save financial resources, increase efficiency and productivity, save office space. Moreover, it eases documentation and information retrieving process; generally the process is more secure and helps to save the environment (Sellen \& Harper, 2001). Eventually, Forbes suggested five course action plans to develop paperless office (Harrison, 2013) as follows;

\subsection{Internal Documentation}

The ministry needs to create back office environment towards paperless office. First and most hectic tasks would be to convert hard copies to digital form. Currently, the ministry keeps records and processes existing 10.1 million applications. Moreover, around 3\% new employees join Saudi Arabia labor force every year (Central Department of Statistics and Information, 2013). In order to digitalize these documents Saudi government needs to employ university students to finish this task. Government data shows that in 2006, some 636,245 students (Ministry of Enomony and Planning, 2007) got enrolled in Saudi higher education institutions. The ministry can form a project and employ required number of students to finish this task. Secondly, the ministry needs to create an environment of sharing files without printing any paper. Here it can be mentioned that Google Docs and Drop box is an excellent program to work simultaneously. Sharing is also easy, it can be done without printing. Google Docs allows users to have e-conversation with other users while working on same file. The program automatically saves data in the file. If ministry wants to use closed source software instead of open source than the ministry can use Microsoft Office 365. It provides all kind of data sharing and interactive data editing solutions. Basecamp is another open source solution which allows users to collaborate document and share. But this program has limitations. It does not allow two users to work simultaneously (Harrison, 2013).

\subsection{Paperless Statements and Bill Paying}

Saudi government and commercial banks already implemented online banking system in Saudi Arabia so the ministry needs to adopt online transactions instead of using traditional billing system. Currently, the ministry uses invoices, checks and mailing for financial 
transactions. Moreover, the ministry needs to use paperless statements, it is easier to store and retrieve. Nowadays, banks provide customized service to corporate clients. It also provides required trainings. So the ministry can arrange customized training program for its employees so that they can effectively use online banking tool (Harrison, 2013).

\subsection{Storage and File Sharing}

As it was said that the ministry needs to digitalize its documents, now the ministry needs a place to store its large database. The ministry can consider using DropBox because it allows user to create group folders for different parties and department members. Thus the ministry can store data and disseminate reports when required (Harrison, 2013).

\subsection{Meetings and Printouts}

There are computer applications which can be used to conduct survey and schedule a meeting e.g. Doodle, SurveyMonkey, whenisgood.net. these programs are open source and free. Team Viewer is an excellent office pacage which allows user to have access to home or office computer while on the go. That means the user can access to any file stored in his home and office computer from a remote location. Therefore, there will be no need for printouts and handouts. The program also facilitates teleconferencing, presentations, sharing files, transmitting videos (Harrison, 2013).

\subsection{Front Office Creation}

This is another important task as in this phase the ministry meets the end user, the ultimate user of the services provided by the ministry. The ministry can cater the need of end user in two ways. Firstly, developing an employment portal, where potential or existing employees can meet their needs sitting at home or in the office. The applicants do not need to show up in ministry office to apply for a job or extension. There should be a Standard Operating Procedure (SOP) so that the stakeholders can know how the application will be processed and how long it might take. Moreover, if any applicant needs information and they visit ministry office, instead of paper based brochure, the ministry can distribute Compact Disks containing all required information. The ministry can arrange regular trainings and mentoring programs for computer illiterate job applicants. Moreover, the ministry should provide IT infrastructure support for those who do not possess a computer. This can be done by opening public computer labs with only ministry of labor service functionality to avoid misuse.

This policy is proposed in line with Patton and Sawicki's Basic Methods of Policy Analysis and Planning. This policy proposal has six attributes (Patton \& Sawicki, 1993). Firstly, the problem should be well defined. In this case Saudi Arabia local labor force as well as private companies and expatriates are facing difficulties due to paper intense procedures. Extensive use of paper is causing negative secondary effects on environment as well. Secondly, the evaluation criteria are measurable. The report proposes two interlinked policies. The first one is to create back office environment by adapting 4 strategies towards making a paperless office. The second policy suggests creating front office environment by developing employment portal similar to Malaysia's Electronic Labor Exchange (ELX) and electronic information dissemination system. Thirdly, the policy proposal needs to identify alternative 
policy. In this context as the current system is ineffectively functioning, therefore the ministry needs to develop hassle free and more user friendly experiences. The ministry can do so by implementing paperless office management. Fourthly, the policy needs to evaluate alternative policy. In different phases the report highlighted the necessity of adopting this e-government policy. The outcome should be measurable. In this context, the outcome would be increase in local national's participation in labor market as well as satisfied private companies while dealing with employment issues with labor ministry. Customer satisfaction can be measured using digital survey instruments in order to understand the actual implication of the project. Fifthly, the proposal needs to select a policy from policy proposed and alternative policy. This report only focuses on prospect of paperless management in Saudi Arabia public offices, so in this context two interlinked policies are proposed and both needs to be implemented together. Finally, the policy needs to be implemented (Patton \& Sawicki, 1993). Few implementation strategies were proposed in the alternative policy chapter.

\section{Conclusion and Recommendations}

This policy paper proposes a policy which can face legislative and cultural barriers. Saudi work system is highly traditional. It would be slightly difficult to convince the policy makers about the importance of paperless office management. UN report shows that Saudi Arabia is moving fast towards becoming an e-government leader. This policy can capitalize this prospect and manage to convince the policy makers that this policy is timely and much anticipated. Moreover, this will reduce environmental footprints, which will contribute positively towards Saudi government's reputation. The next difficult part is to convince the Ministry employees to change their habit of dealing with papers. Many employees will resist change at the beginning but smart policy makers include end users while policy making. Study shows that if employees are given the situation and nature of the problems, they use their skills and knowledge and come up with the same policy or sometimes better policy, which makes it very easy to implement because employees believe that policy was developed by them in response to current need. Instead of facing resistance, the ministry can expect enthusiasm from employee's side. Last but not least, the Ministry needs to ensure accessibility and acceptability of newly developed policy. The Ministry can do this by extensive campaign, trainings and IT infra-structure support.

\section{References}

Al-Khafaji, N.J., Shittuline, A. J., \& Osman, W, R. (2012). The effect of resistance to change in the application of e-Government in Iraq. Tenth International Conference on ICT and Knowledge Engineering, 99-103. http://dx.doi.org/10.1109/ICTKE.2012.6408579

AL-Zuabi, H. F., \& Al- Shaikhli, I. F. (2013). Evaluation of usability problems of labor portal in Saudi Arabia. International Journal of Advanced Computer Science and Information Technology (IJACSIT), 2(1), 14-25.

AME. (2011). Middle East paper market to consume 29 million tons of paper by 2020, despite digital media growth. [Online] Available at: http://www.ameinfo.com/275456.html 
Central Department of Statistics and Information. (2013). Latest statistical Releases. [Online] Available at: http://www.cdsi.gov.sa/english/

Greenblue. (2013). Environmentally Preferable Paper Defined. [Online] Available at: https://www.epat.org/Page.aspx?request=122\#3

Harrison, K. (2013). 5 Steps To A (Nearly) Paperless Office. [Online] Available at: http://www.forbes.com/sites/kateharrison/2013/04/19/5-steps-to-a-nearly-paperless-office/ Hwang, M.-S., Li, C.-T., \& Chu, Y.-P. (2004). Challanges in E-Government and Security of Information. Information \& Security, 15(1), 9-20.

ILO. (2011). G20 Country Policy Briefs: Saudi Arabia. Strategy Reprt. Paris: International Labor Organization.

Jaeger, P.T., \& Thompson, K.M. (2003). E-government around the world: Lessons, challenges, and future directions. Government Information Quarterly, 20(1), 389-394. http://dx.doi.org/10.1016/j.giq.2003.08.001

Janowski, T. (2003). Introduction to Electronic Government. Macau: United Nations University Center for Electronic Governance.

Jeffreys, A. (2009). The Report: Saudia Arabia. Investment Report. Saudi Arabia: Oxford Oxford Business Group.

Madden, N. (2009). Sustainability Software, Part 2: Cutting the Paper Chase. [Online] Available at: http://www.technewsworld.com/story/68834.html.

Martin, S., 2004. Paper Chase. [Online] Available at: http://web.archive.org/web/20070619104819/http://www.ecology.com/feature-stories/paper-c hase/index.html.

Michigan State University. (2011). Saudi Arabia Economy. [Online] Available at: https://globaledge.msu.edu/countries/saudi-arabia/economy

Ministry of Enomony and Planning. (2007). Latest News. [Online] Available at: http://www.mep.gov.sa/themes/GoldenCarpet/index.jsp\#1369226230153

Ministry of Labour Saudi Arabia. (2013). About Us. [Online] Available at: http://www.mol.gov.sa/

Murphy, C. (2011). Private sector in Saudi Arabia faces punishment for not cutting expat payroll. [Online] Available at: http://www.thenational.ae/news/world/middle-east/private-sector-in-saudi-arabia-faces-punis hment-for-not-cutting-expat-payroll

National Geographic. (2013). Paper Buying Guide. [Online] Available at: http://environment.nationalgeographic.com/environment/green-guide/buying-guide/paper/env ironmental-impact/ 
Noor, Z.M., Kasimin, H., Aman, A., \& Sahari, N. (2011). An Adoption Model of Electronic Government Services in Malaysia: Electronic Labor Exchange (ELX). Jurnal Pengurusan, 33(1), 87 - 97.

Patton, C.V., \& Sawicki, D.S. (1993). Basic Methods of Policy Analysis and Planning. 2nd ed. New Jersey: Prentice Hall.

Reuters. (2012). Saudi to start fining firms with expat majorities. [Online] Available at: http://www.arabianbusiness.com/saudi-start-fining-firms-with-expat-majorities-479458.html

Reuters. (2013). Half of jobless Saudis have never applied for work. [Online] Available at: http://www.arabianbusiness.com/half-of-jobless-saudis-have-never-applied-for-work-490311. html

Reuters. (2013). Saudi reforms add 600,000 private sector jobs. [Online] Available at: http://www.arabianbusiness.com/saudi-reforms-add-600-000-private-sector-jobs-494186.htm 1

Saudi Government. (2013). THE BASIC LAW OF GOVERNANCE. [Online] Available at: http://www.saudiembassy.net/about/country-information/laws/The_Basic_Law_Of_Governa nce.aspx

Seifert, J.W. (2013). A Primer on E-Government: Sectors, Stages, Opportunities, and Challenges of Online Governance. Congressional Research Service. Washington: The Library of Congress.

Sellen, A.J., \& Harper, R.H.R. (2001). The Myth Of The Paperless Office. 1st ed. Cambridge: MIT Press.

Shane, D. (2012). Prince Alwaleed lauds scheme to fine expat majority firms. [Online] Available at: http://www.arabianbusiness.com/prince-alwaleed-lauds-scheme-fine-expat-majority-firms-48 1570.html

Shane, D. (2013). Saudisation has created 410,000 jobs, says gov't. [Online] Available at: http://www.arabianbusiness.com/saudisation-has-created-410-000-jobs-says-gov-t-501677.ht $\mathrm{ml}$

The Star Online. (2006). ELX helping Malaysians find jobs. [Online] Available at: http://thestar.com.my/news/story.asp?file=/2006/8/29/nation/15266102\&sec=nation

UNPAN. (2008). Electronic Labor Exchange (ELX). [Online] Available at: http://www.unpan.org/DPADM/EGovernment/KnowledgeBaseofEGovernmentPractices/tabi d/828/ctl/StudyView/mid/2148/CaseStudyID/65/language/en-US/Default.aspx

US EPA. (2012). Municipal Solid Waste. [Online] Available at: http://www.epa.gov/epawaste/nonhaz/municipal/index.htm

World Bank. (2013). Rural population (\% of total population). [Online] Available at: http://data.worldbank.org/indicator/SP.RUR.TOTL.ZS/countries/SA?display=graph 